\section{EXPERIENCE OF MAKESHIFT SPINAL CORD INJURY REHABILITATION CENTER ESTABLISHED AFTER THE 2005 EARTHQUAKE IN PAKISTAN}

\section{To the Editor:}

Spinal cord injuries (SCIs) are frequently reported in earthquakes. ${ }^{1-3}$ Pakistan is among 9 countries that account for more than $80 \%$ of earthquake-related injuries. ${ }^{4}$ An earthquake on October 8, 2005, in Kashmir, Pakistan, left more than 73,000 persons dead. This earthquake resulted in an estimated 650 to 750 SCIs. ${ }^{5}$ Management of SCI victims offered challenges such as saturation of available SCI rehabilitation services and aggravation of injuries by improper immobilization, lifting, and transport techniques. ${ }^{1,6-8}$ It was reported that several makeshift SCI rehabilitation centers, which were established after the earthquake, may have benefited these victims. ${ }^{9}$ However, structure, function, and outcome of these centers were never described. ${ }^{1,5,9}$

In the district headquarter (DHQ) hospital, 93 SCI patients were admitted after the earthquake. Patients were mostly aged 16 to 39 years $(63[68 \%])$ and were women $(56[60 \%])$. The need for an SCI rehabilitation center was strongly felt when physicians from the department of medicine, who directly par- ticipated in care of these patients in a makeshift arrangement, observed a high prevalence of pressure ulcers in the patients. After obtaining necessary authorizations, a makeshift SCI rehabilitation center was established in the DHQ hospital under the auspices of the department of medicine. This center remained functional from November 1, 2005, to April 30, 2006. A description of the care model implemented in this makeshift rehabilitation center compared with previous arrangements is given. The observations were made during a period from October 8 to December 24, 2005. The study was approved by the institutional review board of the Rawalpindi Medical College and the DHQ hospital.

It was observed that this care model improved the provision of health care resources to SCI patients compared with those previously available. Additional paramedical staff was recruited temporarily by the funds made available by different nongovernmental organizations (NGOs). The center was coordinated by a senior medical officer from the department of medicine. Visits of surgical, medical, and urological specialists were regular in contrast with previous arrangements whereby they were contacted only when a call was made by an attending physician (Table). All patients were systematically trained in bladder care. A physiotherapist from the Armed Forces Institute of Reha-

\title{
TABLE
}

\section{Comparison of the Neurosurgical Ward and Spinal Cord Injury (SCI) Rehabilitation Center Established After the Earthquake in Pakistan in 2005}

\section{Human resources}

Neurosurgical consultants

Surgical consultants

Medical physician

Urologist

Rehabilitation specialist

Nutritionist

Psychologist

Social workers

Coordinator

Residents

Interns

Nurses

Dressers

Ward servants

Sweepers

Physiotherapists

Physiotherapist assistants

Physical resources

Beds

Rehabilitation gym

Wheelchairs

Crutches/corsets

Miscellaneous

Regular rehabilitation exercises None

Psychological counseling None

Meals

3 available $24 \mathrm{~h}$
On consultation
On consultation
On consultation
None
None
None
None
None
2 available $24 \mathrm{~h}$
2 available $24 \mathrm{~h}$
2 available $24 \mathrm{~h}$
1 available $6 \mathrm{~h}$
1 available $24 \mathrm{~h}$
1 available $24 \mathrm{~h}$ (undedicated)
1 available $6 \mathrm{~h}$
None
70
None
2 available for all patients
None
None
None
None

3 available $24 \mathrm{~h}$
1 available $24 \mathrm{~h}$
1 available $24 \mathrm{~h}$
Twice-weekly visits
Twice-weekly visits
Weekly visits
Daily visits
Daily visits
Available $24 \mathrm{~h}$
2 available $24 \mathrm{~h}$
2 available $24 \mathrm{~h}$
3 available $24 \mathrm{~h}$
1 available $24 \mathrm{~h}$
2 available $24 \mathrm{~h}$
1 available $24 \mathrm{~h}$
3 available $6 \mathrm{~h}$
15 available $12 \mathrm{~h}$

90

Available

Available for each patient Available for each patient

Daily for each patient 30 min daily per patient High protein 3 times daily 
bilitation Medicine and the NGO Handicap International regularly visited and trained volunteers in rehabilitation exercises. Furthermore, SCI victims were assessed regularly by visiting psychologists and nutritionists.

Physical resources such as specialized beds, wheelchairs, and crutches were provided to all patients, which was not the case before. A rehabilitation gym was established within the ward in which regular rehabilitation exercises were carried out. Moreover, protein meals were provided to all patients 3 times a day. Funding for all of these additional resources was provided by NGOs.

Daily progress of all SCI victims was collected in this center by medical residents. More than two thirds of the patients $(65$ [70\%]) had surgical interventions (spinal fixation), whereas the others (28 [30\%]) were managed conservatively. Prognosis of SCI was measured daily from admission to discharge by a consultant physician using the American Spinal Injury Association impairment score. ${ }^{10}$ During the period from November 1 to December 24, 2005, an improvement in injury score was observed in 36 of 93 patients. In 14 patients, pressure ulcers developed, only 1 was grade 4 . One patient had deep venous thrombosis, whereas the single death that occurred in the defined period was due to pulmonary embolism.

In this care model, coordination among the different services was an important element. Direct involvement of a member of the department of medicine as the coordinator was paradoxical because patients were admitted primarily because of surgical conditions. However, resource limitation in such an extraordinary situation was the major reason for these arrangements. Our experience showed that this may have benefited victims and the health care system in following ways: (1) relieving surgeons to take care of patients with other types of injuries and (2) identification of medical conditions that are frequently fatal in patients with SCIs, such as pneumonia, respiratory problems (atelactasis), heart disease, subsequent trauma, septicemia, and deep venous thrombosis. ${ }^{11}$

It is possible that regular visits of surgical specialists might have prevented emergent surgical conditions such as pressure ulcers, wound infections, and urinary tract infections in SCI patients. ${ }^{12,13}$ However, it is difficult to draw such conclusions on the basis of available data. Nevertheless, establishment of this center provided a forum for offering rehabilitation services in a resource-poor setting. ${ }^{14}$ Indeed, this center facilitated engaging volunteers to care for patients and procuring required rehabilitation material from NGOs. Similarly, psychological and social services, which are essential in SCI rehabilitation, were provided to patients under the auspices of this center. ${ }^{15}$

These observations showed that necessary arrangements could be made to meet the needs of an overwhelming number of SCI patients. Several lessons can be learned from implementation of this care model. When SCI rehabilitation centers become saturated after such disasters, it might be useful to consider es- tablishing makeshift rehabilitation centers. Furthermore, it is appropriate to establish such centers in the nearest available tertiary care centers. Finally, a coordinating body is necessary to ensure timely availability of multiple health care services.

Bilal Arshed Butt, MBBS, MPH
Junaid Ahmad Bhatti, MBBS, MSc
Muhammad Shahzad Manzoor, MBBS, FCPS
Khurram Saleem Malik, MBBS
Muhammad Shoaib Shafi, MBBS, FCPS

Acknowledgments: We thank Asif Raza Bhatti, MBBS, Naheela Afzal, MBBS, Raheel Rabbani, MBBS, Sher Bahadur Khan, MBBS, Arshad Iqbal Satti, MBBS, FCPS, Sister Tasneem, Sister Razia, Sister Jabeen, Sister Fozia, Sister Raffat, Sister Sofia, Mr Arshad, Mr Shabbir, Mr Abid, Mr Akhter, all from the DHQ Teaching Hospital, Rawalpindi and Armed Forces Institute of Rehabilitation Medicine, Handicap International, for help at various stages in compilation of this study.

Author Affiliations: Department of Medicine, DHQ Teaching Hospital/ Rawalpindi Medical College, Rawalpindi, Pakistan (Drs Butt, Manzoor, Malik, and Shafi); Research team Avenir "Injury Prevention and Control" (PPCT), French National Institute for Health and Medical Research (INSERM) Unit 897, University Victor Segalen Bordeaux 2, Bordeaux, France (Dr Bhatti).

Correspondence: Bilal Arshed Butt, MBBS, MPH, District Headquarters Hospital, Rawalpindi, Pakistan (drbilalbutt@hotmail.com).

\section{REFERENCES}

1. Priebe MM. Spinal cord injuries as a result of earthquakes: lessons from Iran and Pakistan. J Spinal Cord Med. 2007;30(4):367-368.

2. Maruo S, Matumoto M. Spinal fractures resulting from the 1995 Great Hanshin earthquake of the Kobe-Osaka area of Japan. Spinal Cord. 1996; 34(7):382-386.

3. Raissi GR. Earthquakes and rehabilitation needs: experiences from Bam, Iran. J Spinal Cord Med. 2007;30(4):369-372.

4. Briggs SM. Earthquakes. Surg Clin North Am. 2006;86(3):537-544.

5. Rathore MF, Rashid P, Butt AW, Malik AA, Gill ZA , Haig AJ. Epidemiology of spinal cord injuries in the 2005 Pakistan earthquake. Spinal Cord. 2007;45(10):658-663.

6. World Health Organization. Coping With Natural Disasters: The Role of Local Health Personnel and the Community Working Guide. Geneva, Switzerland: World Health Organization; 1989.

7. Sheng ZY. Medical support in the Tangshan earthquake: a review of the management of mass casualties and certain major injuries. J Trauma. 1987;27(10):1130-1135

8. Burke DC, Brown D, Hill V, Balian K, Araratian A, Vartanian C. The development of a spinal injuries unit in Armenia. Paraplegia. 1993;31(3):168-171.

9. Tauqir SF, Mirza S, Gul S, Ghaffar H, Zafar A. Complications in patients with spinal cord injuries sustained in an earthquake in northern Pakistan. J Spinal Cord Med. 2007;30(4):373-377.

10. American Spinal Injury Association. International Standards for Neurological Classifications of Spinal Cord Injury (Revised). Chicago, IL: American Spinal Injury Association; 2000.

11. Poynton AR, O'Farrell DA, Shannon F, Murray P, McManus F, Walsh MG. An evaluation of the factors affecting neurological recovery following spinal cord injury. Injury. 1997;28(8):545-548.

12. DeVivo MJ. Epidemiology of traumatic spinal cord injury. In: Kirshblum S, ed. Spinal Cord Medicine. Baltimore, MD: Lippincott Williams \& Wilkins, 2002:69-81.

13. Carvell JE, Grundy DJ. Complications of spinal surgery in acute spinal cord injury. Paraplegia. 1994;32(6):389-395.

14. Krause JS, Sternberg M, Lottes S, Maides J. Mortality after spinal cord injury: an 11-year prospective study. Arch Phys Med Rehabil. 1997;78(8): 815-821.

15. Alander DH, Parker J, Stauffer ES. Intermediate-term outcome of cervical spinal cord-injured patients older than 50 years of age. Spine. 1997; 22(11):1189-1192. 